\title{
Smart Water Level Indicator
}

\author{
Ammar Asyraf Ismail ${ }^{1}$, Muhammad Arief Azizi ${ }^{1}$, Asnazulfadhli Zariman ${ }^{1}$ \\ ${ }^{1}$ Department of Computing, Faculty of Arts, Computing and Creative Industry, \\ Universiti Pendidikan Sultan Idris, Malaysia.
}

Article history

Received:

05.01.2020

Revised:

14.02.2020

Accepted:

16.03.2020

*Corresponding Author: Ammar Asyraf bin Ismail Email:

hyrash04@gmail.com

This is an open access article, licensed under: $C C-B Y-S A$
Abstract: The Water Level Indicator is beneficial to the public, especially to residents living in rivers. This technology can provide early warnings to residents when the water level is occupying a dangerous level and facilitates workers who control the dam of the river. This technology can alert early through sirens and notifications / messages via smartphones as well as to the river dashboard controllers capable of controlling water gates through their smartphones. The worker who controls the dam of this river no longer needs to go back to the dam's door control house to open the water dam door. Workers who are in charge of controlling dam need to stand in one place only to open their smartphones and control the dam's doorway using the fingertips. To the people living in the river, they do not have to worry about the floods that will happen in their area. They will get an early warning about the flood at any time even when they are sleeping. They will get the warning via notification on their smartphone and siren is places in a certain area to produce a loud noise so that residents can be prepared to face the disaster. It is expect that the Water Level Indicator is able to take a step further and can be use as best as possible and can help the local community.

Keyword: Internet of Things, Flood, Water Level. 


\section{Introduction}

The Water Level Indicator is beneficial to the public, especially to residents living in rivers. This technology can provide early warnings to residents when the water level is occupying a dangerous level and facilitates workers who control the dam of the river. This technology can alert early through sirens and notifications / messages via smartphones as well as to the river dashboard controllers capable of controlling water gates through their smartphones.

The worker who controls the dam of this river no longer needs to go back to the dam's door control house to open the water dam door. Workers who are in charge of controlling dam need to stand in one place only to open their smartphones and control the dam's doorway using the fingertips. To the people living in the river, they do not have to worry about the floods that will happen in their area. They will get an early warning about the flood at any time even when they are sleeping. They will get the warning via notification on their smartphone and siren is places in a certain area to produce a loud noise so that residents can be prepared to face the disaster. It is expect that the Water Level Indicator is able to take a step further and can be use as best as possible and can help the local community.

\section{Literature Review}

\subsection{Internet of Things}

Internet of Thing (IoT) is a concept where an object has the ability to transfer data through a network without requiring human-to-human or human-computer interaction. IoT has evolved from the convergence of wireless technology, micro-electromechanical systems (MEMS), and the Internet [1] [2] [3] [4] [5].

"A Things" on the Internet of Things can be defined as a subject, for example a person with a heart implant monitor, a farm animal with a biochip transponder, a car that has a built-in sensor to warn the driver when tire pressure is low. So far, IoT is most closely related to machine-to-machine (M2M) communications in manufacturing and electricity, oil and gas [4] [6] [7]. Products are built with M2M communication capabilities which are often referred to as "smart" systems. For example, smart cables, smart meters, smart grid sensors.

In addition, it can also be said that IoT as a global network infrastructure, which connects physical and virtual objects through the exploitation of data capture and communication capabilities [8] [9], [0]. Infrastructure consists of existing networks and the internet and its network development. All of these will offer object identification, sensors and connection capabilities as a basis for the development of independent cooperative services and applications [2] [7] [9] [11] [12]. It is also characterized by a high degree of autonomous data capture, event transfer, network connectivity and interoperability [13].

\subsection{Servo Motor Pinout Wires}

Features of Servo Motor (SG90), namely [10]:

1. Operating Voltage is $+5 \mathrm{~V}$ typically

2. Torque: $2.5 \mathrm{~kg} / \mathrm{cm}$

3. Operating speed is $0.1 \mathrm{~s} / 60^{\circ}$

4. Gear Type: Plastic

5. Rotation : $0^{\circ}-180^{\circ}$

6. Weight of motor : 9gram

7. Package includes gear horns and screws

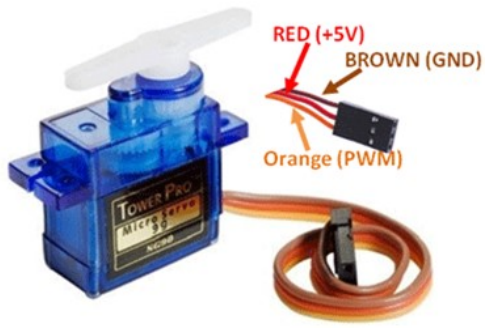

Figure 1. Servo Motor Pinout Wires 
Table 1. Wire Configuration

\begin{tabular}{cc}
\hline Wire Colour & Description \\
\hline Brown & Ground Wire \\
\hline Red & Power Wire typically $+5 \mathrm{~V}$ \\
\hline Orange & PWM signal is given in through this wire to drive the motor \\
\hline
\end{tabular}
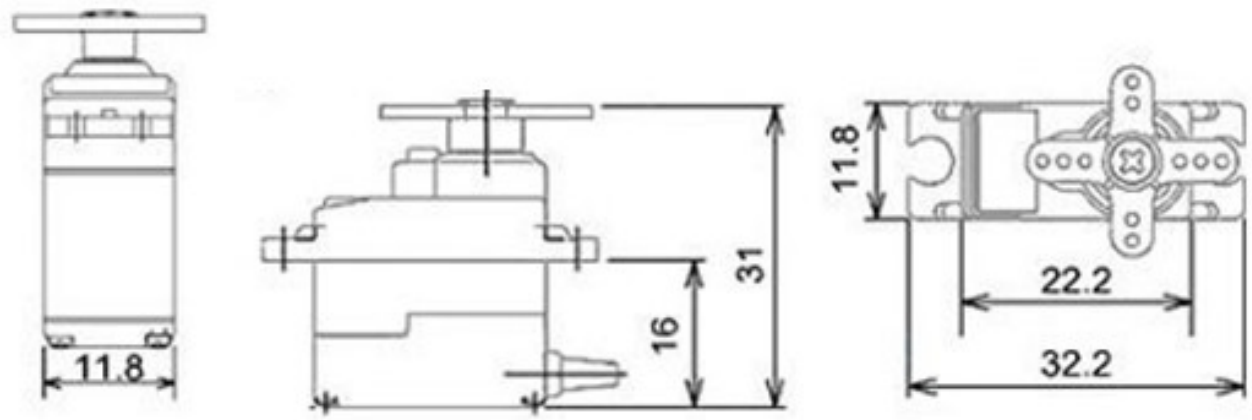

Figure 2. Servo Motor (SG90) Dimensions

\subsection{ESP32 DevKitC (NodeMCU)}

In terms of power and features obviously the dual cored microprocessor powered ESP32 will surely take down the microcontroller powered Arduino UNO. The ESP32 has built in Bluetooth and Wi-Fi with good number of GPIO pins and communication protocols [10].

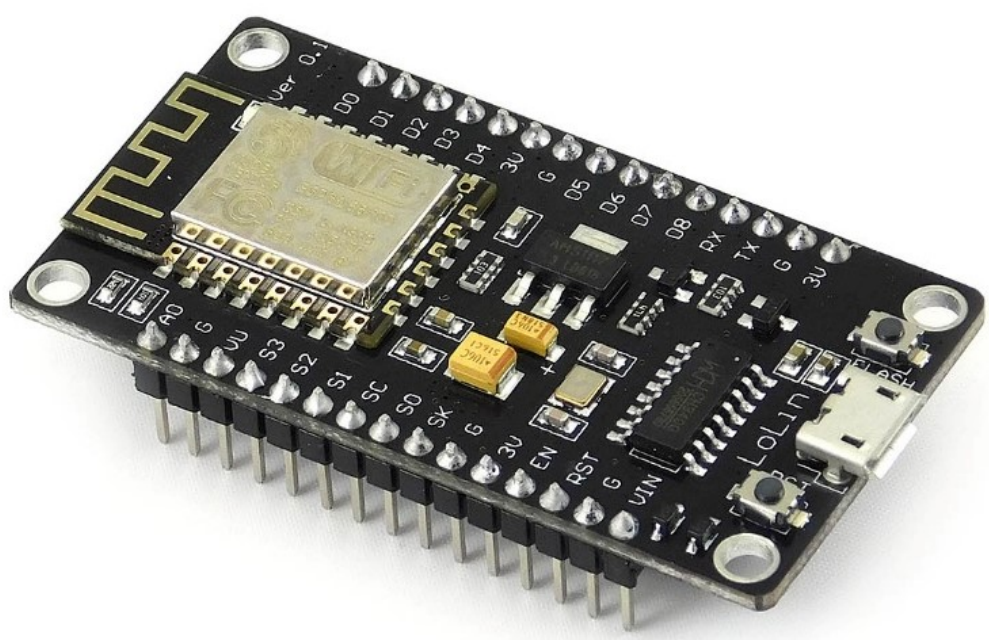

Figure 3. ESP32 DevKitC (NodeMCU)

The ESP32 is design for low power IoT applications in mind. It's high processing power with inbuilt Wi-Fi / Bluetooth and Deep Sleep Operating capabilities makes it ideal for most Portable IoT devices. Also now, since Arduino IDE has officially released board managers for ESP32 it has become very easy to program these devices. 
The ESP32 is design for low power IoT applications in mind. It's high processing power with inbuilt Wi-Fi / Bluetooth and Deep Sleep Operating capabilities makes it ideal for most Portable IoT devices. Also now, since Arduino IDE has officially released board managers for ESP32 it has become very easy to program these devices.

Table 2. Table Technical Specifications for ESP32 DevKitC (NodeMCU)

\begin{tabular}{ll}
\hline Microprocessor & Tensilica Xtensa LX6 \\
\hline Maximum Operating Frequency & $240 \mathrm{MHz}$ \\
\hline Operating Voltage & $3.3 \mathrm{~V}$ \\
\hline Analog Input Pins & 12 -bit, 18 Channel \\
\hline DAC Pins & 8 -bit, 2 Channel \\
\hline Digital Input/Output Pins & 39 (of which 34 is normal GPIO pin) \\
\hline DC Current on Input/Output Pins & $40 \mathrm{~mA}$ \\
\hline DC Current on 3.3V Pin & $50 \mathrm{~mA}$ \\
\hline SRAM & $520 \mathrm{~KB}$ \\
\hline Communication & SPI(4), I2C(2), I2S(2), CAN, UART(3) \\
\hline Wi-Fi & $802.11 \mathrm{~b} / \mathrm{g} / \mathrm{n}$ \\
\hline Bluetooth & V4.2 - Supports BLE and Classic Bluetooth \\
\hline
\end{tabular}

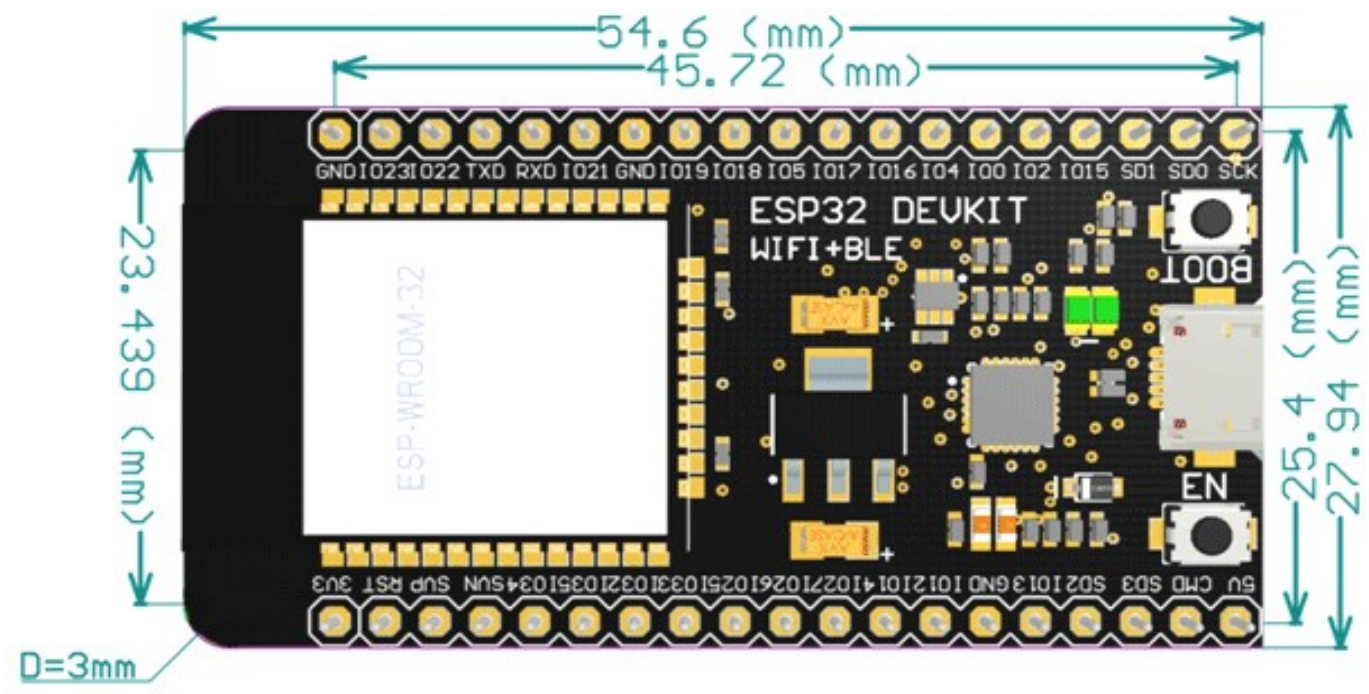

Figure 4. ESP32 2D Model 
There are three ways by which to power an ESP32 board, namely:

1. Micro USB Jack

Connect the mini USB jack to a phone charger or computer through a cable and it will draw power required for the board to function

2. 5V Pin

The $5 \mathrm{~V}$ pin can be supplied with a Regulated $5 \mathrm{~V}$, this voltage will again be regulated to $3.3 \mathrm{~V}$ through the on-board voltage regulator. Remember ESP32 operated with 3.3V only.

3. $3.3 \mathrm{~V}$ Pin

With a regulated $3.3 \mathrm{~V}$ supply then it is directly provide to the $3.3 \mathrm{~V}$ pin of the ESP32.

\subsection{Arduino Uno}

Arduino Uno is a microcontroller board based on 8-bit ATmega328P microcontroller [11]. Along with ATmega328P, it consists other components such as crystal oscillator, serial communication, voltage regulator, etc. to support the microcontroller. Arduino Uno has 14 digital input/output pins (out of which 6 can be used as PWM outputs), 6 analog input pins, a USB connection, A Power barrel jack, an ICSP header and a reset button.

The 14 digital input/output pins can be used as input or output pins by using pinMode(), digitalRead() and digitalWrite() functions in arduino programming. Each pin operate at $5 \mathrm{~V}$ and can provide or receive a maximum of $40 \mathrm{~mA}$ current, and has an internal pull-up resistor of $20-50 \mathrm{KOhms}$ which are disconnected by default.

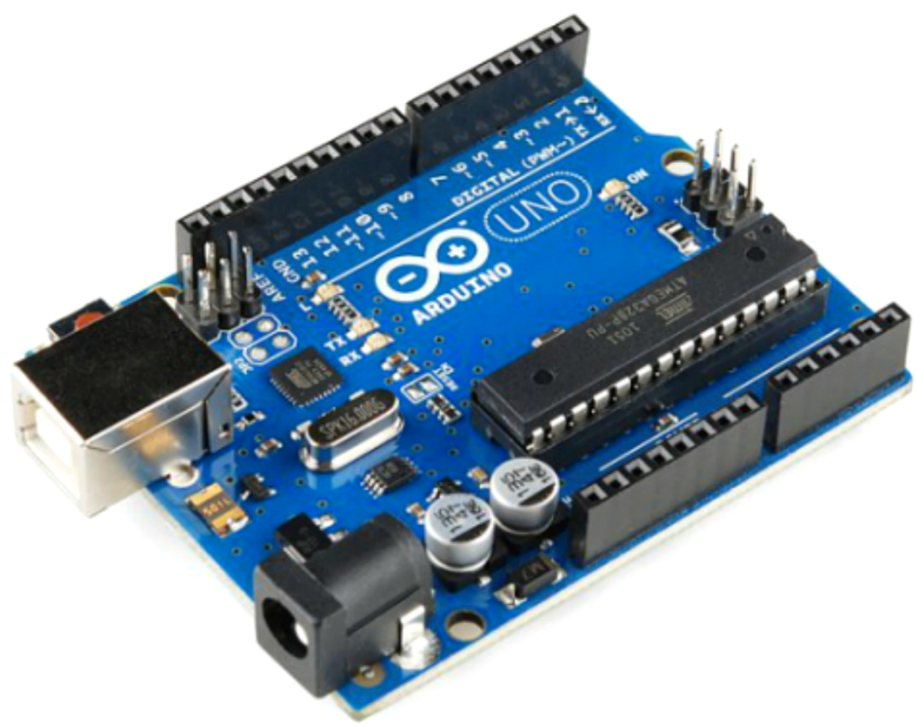

Figure 5. Arduino Uno

Out of these 14 pins, some pins have specific functions as listed:

1. Serial Pins $0(\mathrm{Rx})$ and $1(\mathrm{Tx})$ : $\mathrm{Rx}$ and Tx pins are used to receive and transmit TTL serial data. They are connected with the corresponding ATmega328P USB to TTL serial chip.

2. External Interrupt Pins 2 and 3: These pins can be configured to trigger an interrupt on a low value, a rising or falling edge, or a change in value.

3. PWM Pins 3, 5, 6, 9 and 11: These pins provide an 8-bit PWM output by using analogWrite() function.

4. SPI Pins 10 (SS), 11 (MOSI), 12 (MISO) and 13 (SCK): These pins are used for SPI communication.

5. In-built LED Pin 13: This pin is connected with a built-in LED, when pin 13 is HIGH - LED is on and when 13 pin is LOW, it is off. 
Along with 14 Digital pins, there are 6 analog input pins, each of which provide 10 bits of resolution, i.e. 1024 different values. They measure from 0 to 5 volts but this limit can be increased by using AREF pin with analog Reference () function.

Analog pin 4 (SDA) and pin 5 (SCA) also used for TWI communication using Wire library.

Arduino Uno has a couple of other pins as explaination.

AREF : Used to provide reference voltage for analog inputs with analogReference () function.

Reset Pin : Making this pin LOW, resets the microcontroller.
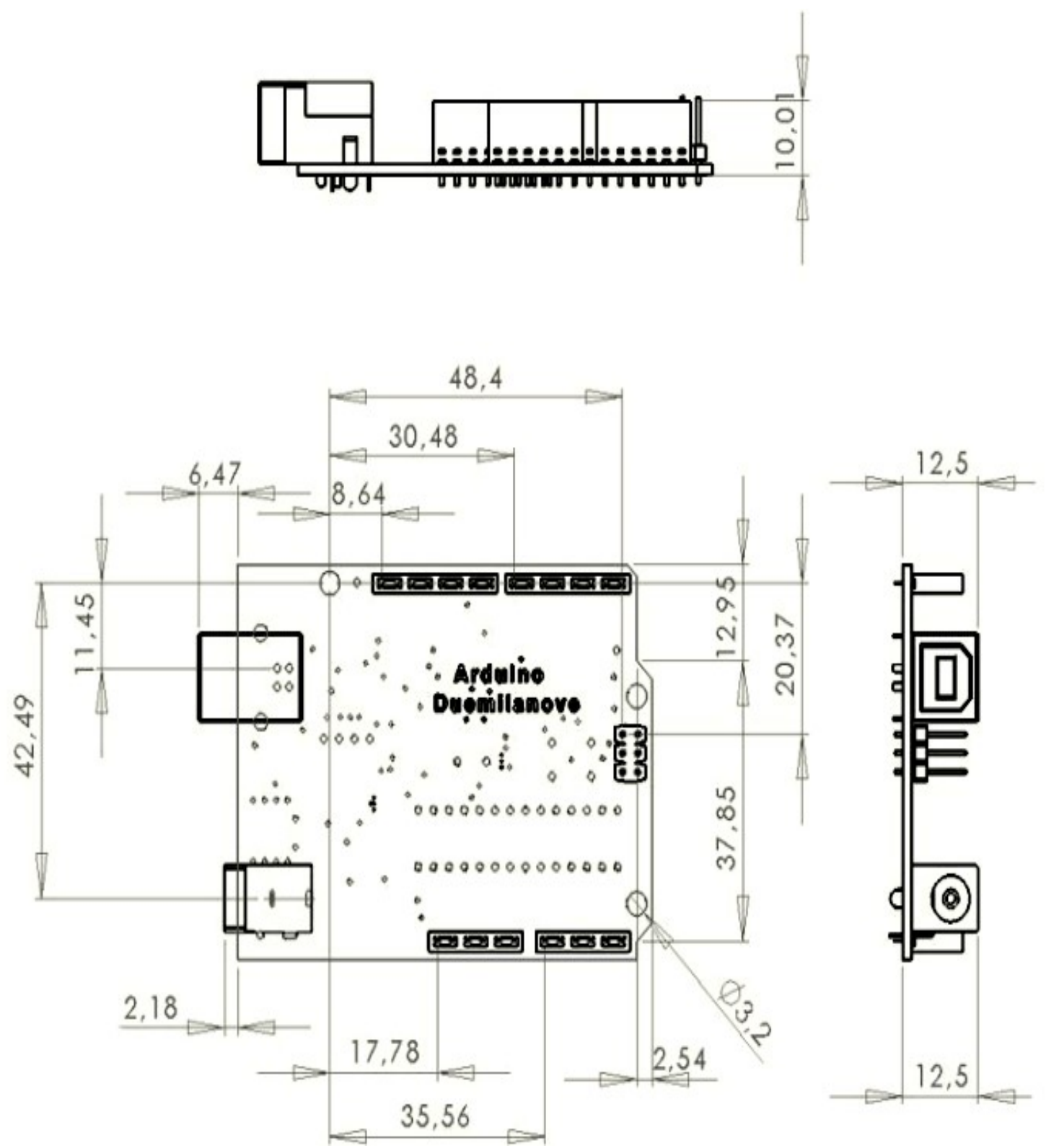

Figure 6. Arduino Uno 2D Model 
Table 3. Arduino Uno Technical Specifications

\begin{tabular}{ll}
\hline Microcontroller & 8 bit AVR family microcontroller \\
\hline Operating Voltage & $5 \mathrm{~V}$ \\
\hline Recommended Input Voltage & $7-12 \mathrm{~V}$ \\
\hline Input Voltage Limits & $6-20 \mathrm{~V}$ \\
\hline Analog Input Pins & $6(\mathrm{~A} 0-\mathrm{A} 5)$ \\
\hline Digital Input/Output Pins & $14($ Out of which 6 provide PWM output $)$ \\
\hline DC Current on Input/Output Pins & $40 \mathrm{~mA}$ \\
\hline DC Current on 3.3V Pin & $50 \mathrm{~mA}$ \\
\hline Flash Memory & $32 \mathrm{~KB}(0.5 \mathrm{~KB}$ is used for Bootloader $)$ \\
\hline SRAM & $2 \mathrm{~KB}$ \\
\hline EEPROM & $1 \mathrm{~KB}$ \\
\hline Frequency (Clock Speed) & $16 \mathrm{MHz}$ \\
\hline
\end{tabular}

\subsection{Resistor}

Resistors have two leads, there is no polarity for a resistor and hence can be connected in both directions.

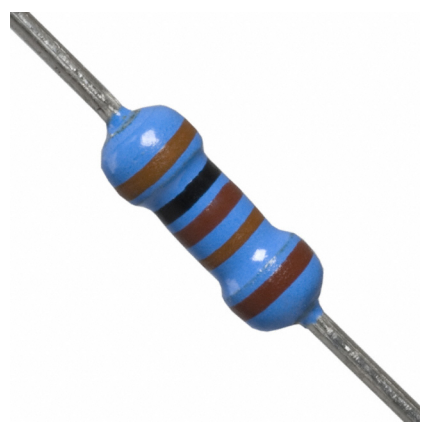

Figure 7. Resistor 301k

The value of resistor gets inversely added up when they are parallel and the value of resistors get added up when they are place in series.

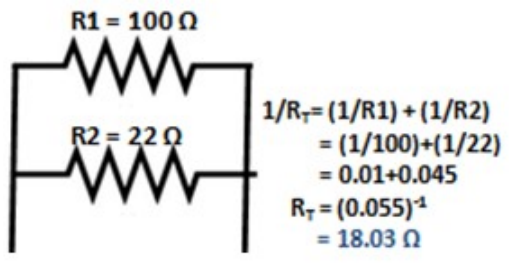

(a)

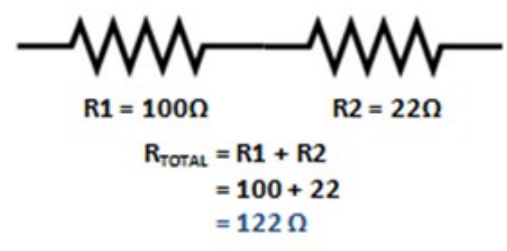

(b)

Figure 8. Resistor Value

(a) Resistor in Parallel

(b) Resistor in Series 
In order to identify the resistance value of a Resistor, we have to look at its colour code. It would have been easy if the value was directly written, but still with little practise from below we can start reading the resistor values.

Resistors are not available in all values. Therefore, if you project needs a particular value which is not commonly available then you have to make up the value by using either series or parallel combination in Figure 9.

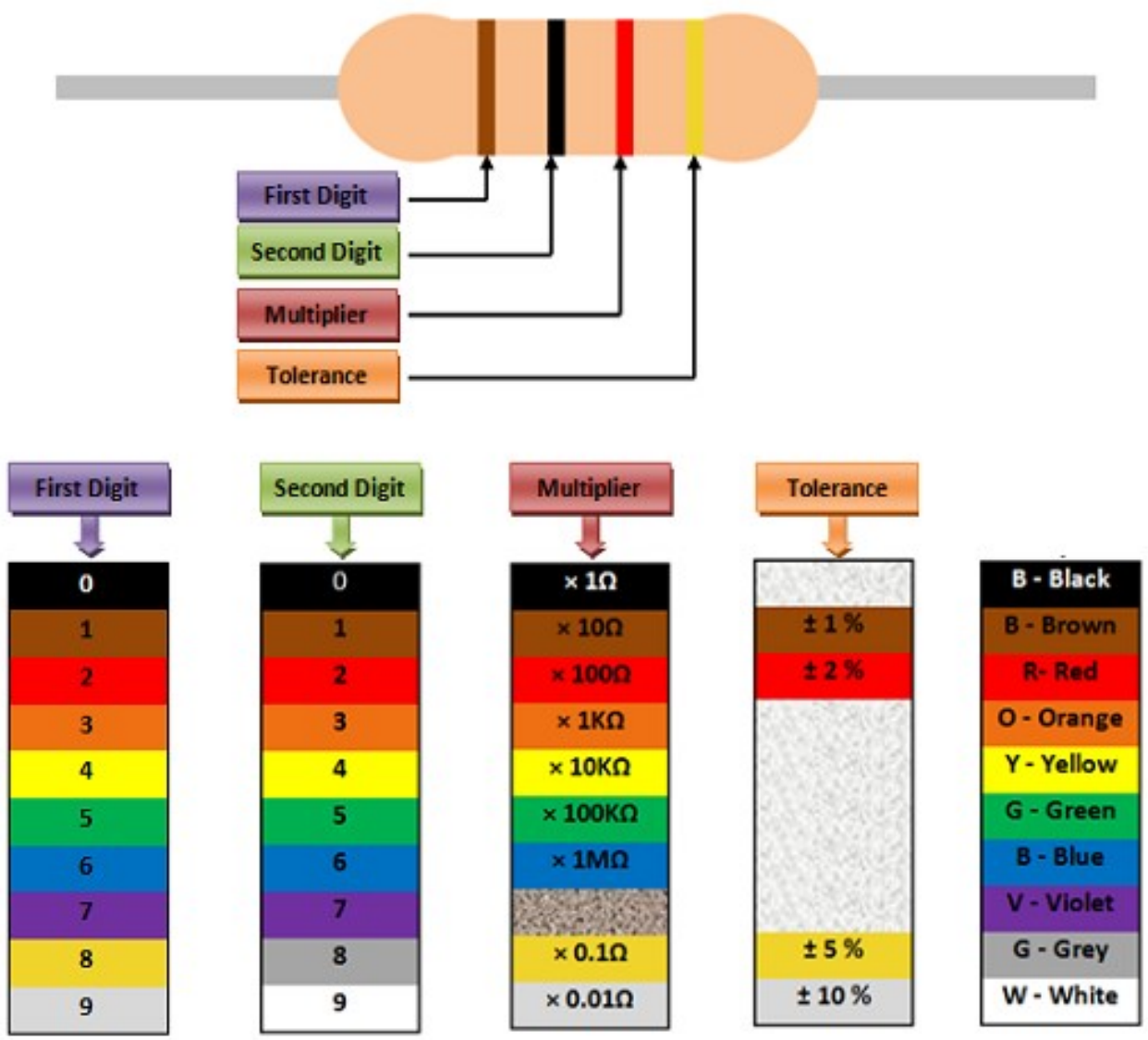

Figure 9. Parallel Combination

\subsection{BC547 Transistor}

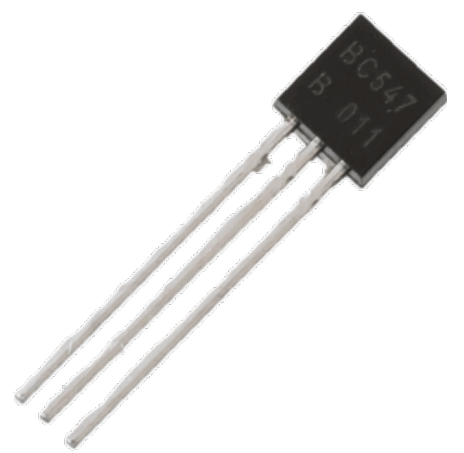

Figure 10. BC547 Transistor 
Table 4. Pin Configuration

\begin{tabular}{ccc}
\hline Pin Number & Pin Name & Description \\
\hline 1 & Collector & Current flows in through collector \\
\hline 2 & Base & Controls the biasing of transistor \\
\hline 3 & Emitter & Current Drains out through emitter \\
\hline
\end{tabular}

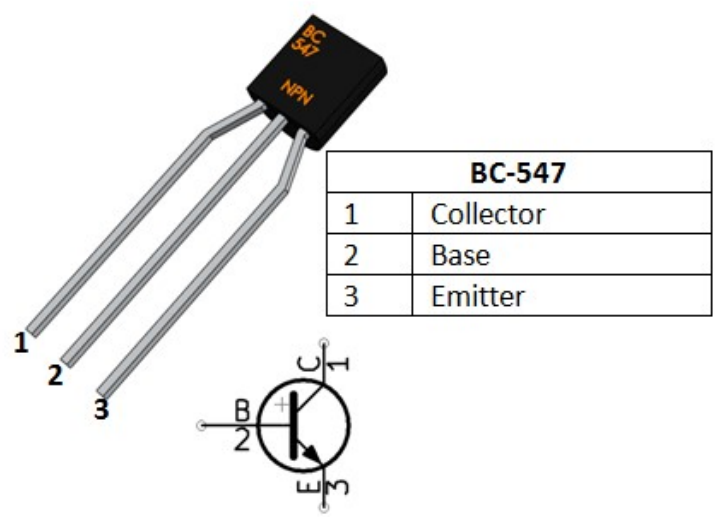

Figure 11. BC547 Transistor Pinout
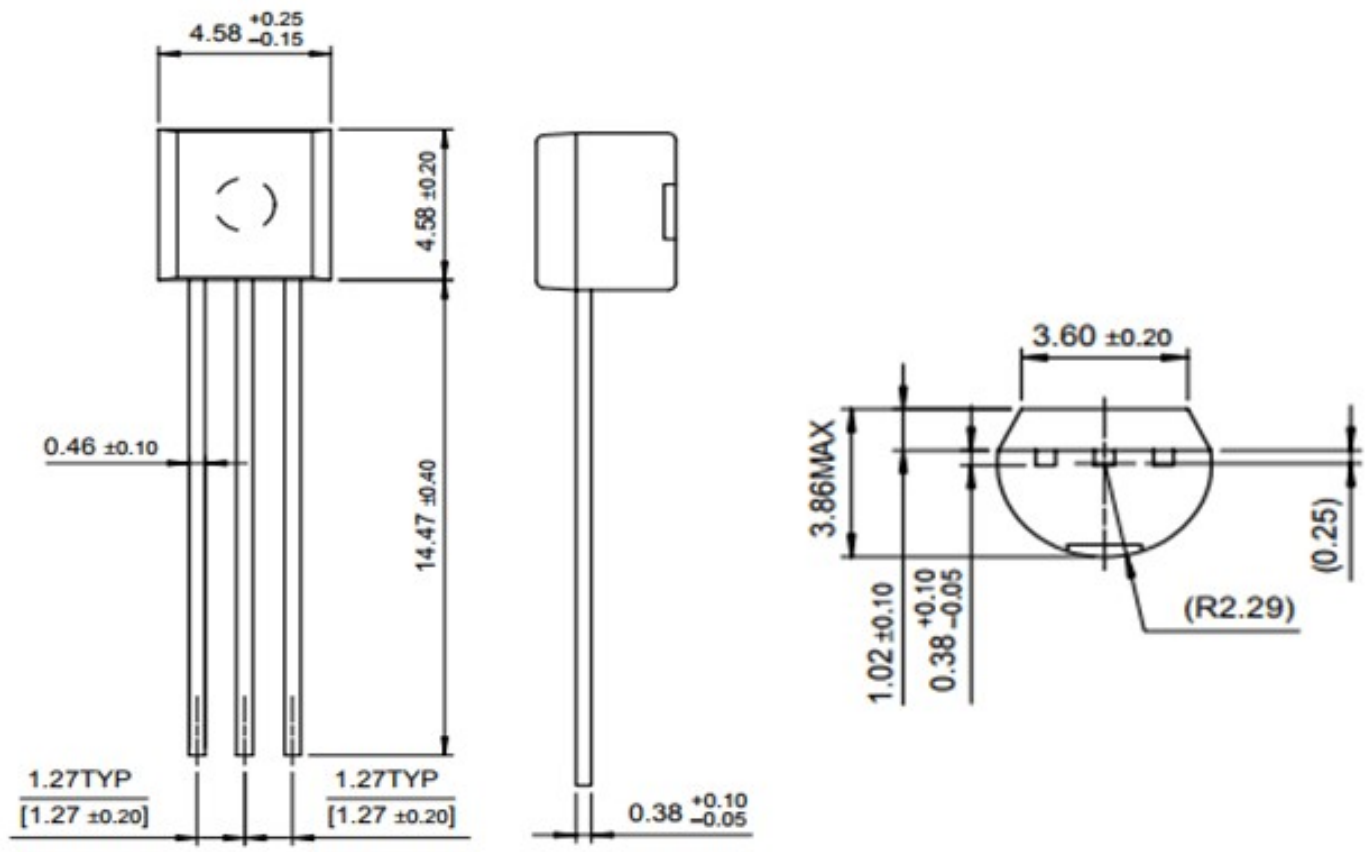

Figure 12. 2D Model of the Component: BC547 Transistor 


\section{Method}

Smart Water Level Indicator is design using the Agile Development Methodology (Continuous Deployment) method. Through this method, information gathering has been conduct by creating a question form (google docs) on issues in the river area. In addition, the flow chart diagram is design to facilitate the implementation of the Smart Water Level Indicator, to be more organize and run smoothly.

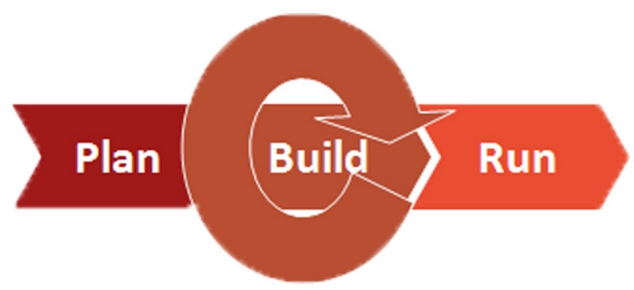

Figure 13. Agile Development Methodology

Through the implementation process, the coding of the Smart water Level Indicator technology has been builed using the existing coding on the Internet and modified according to the suitability of the project. These coding has been changed using Arduino.cc software. Through the test process, a questionnaire was distribute to several samples consisting of UPSI students to test the success of the Smart Level Indicator project to obtain a study on this system.

Finally, the process of development. Through this process, the Smart Level Indicator can be improve and modified after the results of the study of several samples are obtain.

The rationale for producing this technology is with the designed flowchart, as shown in Figure 14.

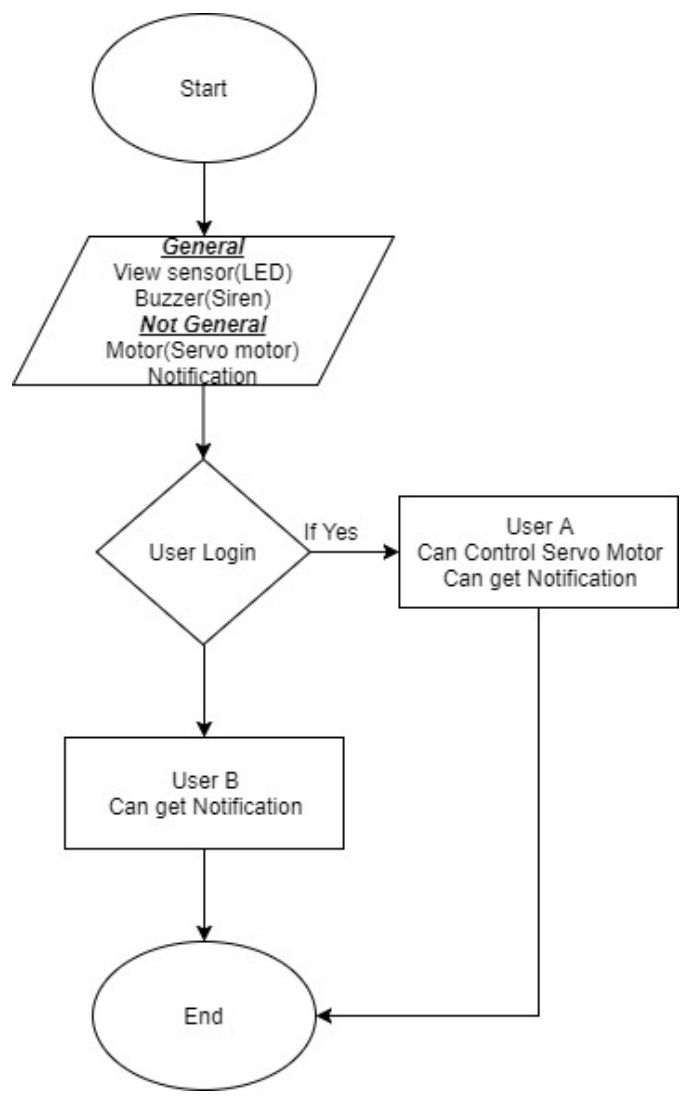

Figure 14. Flowchart for Smart Water Level Indicator 


\section{Testing}

The Smart Water Level Indicator can be work well as requested. We can get the warning by hearing sirens and being notified on the smartphone.

Based on the functionality analysis, it was find that $90 \%$ of consumers said the Smart Water Level Indicator very user friendly and can be used in the future. While $10 \%$ disagree with a reason,

\section{Conclusion}

The Smart Water Level Indicator can benefit the dam gate operators, they can see the river's water level and get an initial warning when the river water is at high level. With that, they do not worry about the river's water level anymore. They can get an earlier warning before the river water flooded out of the river and flooded the area.

The strength of the Smart Water Level Indicator can have a great impact on the community. This technology is capable use just by using smartphones. For example, the dam gate operators can control the dam's door gates by using only smartphones.

\section{References}

[1] Arduino, Language Reference. [Online]. Available: https://www.arduino.cc/reference/en/. [Accessed: August 23, 2019].

[2] Components 101. [Online]. Available: https://components101.com. [Accessed: August 18, 2019].

[3] Autodesk, "Autodesk Tinkercad". [Online]. Available: https://www.tinkercad.com/circuits. [Accessed: August 21, 2019].

[4] L. Adha, Adafruit HUZZAH ESP8266 breakout. [Online]. Available: https://learn.adafruit.com/ adafruit-huzzah-esp8266-breakout/using-arduino-ide. [Accessed: August 18, 2019].

[5] H. Bench, "Arduino ESP8266 LoLin NodeMCU Getting Started." [Online]. Available: http://henrysbench.capnfatz.com/henrys-bench/arduino-projects-tips-and-more/arduino-esp82 66-lolin-nodemcu-getting-started/. [Accessed: August 23, 2019].

[6] ACROBOTIC, "ESP8266 Programming Using Arduino IDE (Mac OSX andWindows)." [Online]. Available: https://www.youtube.com/watch?v=G6CqvhXpBKM. [Accessed: August 21, 2019].

[7] A. Sanjeev, Interface an LCD screen with an Arduino to provide a display for your project. [On-line]. Available: https://maker.pro/arduino/tutorial/how-to-connect-an-lcd-display-to-yourarduino. [Accessed: August 23, 2019].

[8] P. Marian, "Arduino Water Level Indicator + controller." [Online]. Available: https://www.electroschematics.com/9964/arduino-water-level-indicator-controller/. [Accessed: August 23, 2019].

[9] Blynk.io, Getting Started with Blynk. [Online]. Available: https://blynk.io/en/getting-started. [Accessed: August 21, 2019].

[10] M. Ramadhan, "Pengertian, Fungsi, Macam Macam dan Komponen Bendungan." [Online]. Available: https://www.asdar.id/pengertian-fungsi-macam-macam-dan-komponen-bendu ngan/. [Accessed: August 19, 2019].

[11] TatvaSoft, "Top 12 Sofware Development Methodologies \& its Advantages/Diadvantages." [Online]. Available: https://www.tatvasoft.com/blog/top-12-software-development-methodo logies-and-its-advantages-disadvantages/. [Accessed: August 23, 2019].

[12] E. Õunapuu, "Internet of Thing Solution: IoT Design methodology". [Online]. Available: http://johanna.ld.ttu.ee/idu0080/wp-content/uploads/2016/02/Loeng10Lecture_IoTDesign Methodology.pdf. [Accessed: August 23, 2019].

[13] Anynomus, Malaysia Pemilik Telefon Pintar tertinggi ke-10 Dunia. Utusan Online, 2019. [Online]. Available: http://www.utusan.com.my/berita/nasional/malaysia-pemilik-telefonpintar-tertinggi-ke-10-dunia-1.615122. [Accessed: August 19, 2019]. 